\title{
Effect of Co-products on Pd Membrane Performance in Membrane Reforming of Desulfurized Kerosene
}

\author{
Manabu Miyamoto $^{1}$, Chihiro Hayakawa ${ }^{2}$, Yasunori Oumi ${ }^{3}$ and \\ Shigeyuki UemiYa ${ }^{1}$ \\ ${ }^{1}$ Department of Chemistry and Biomolecular Science, Gifu University, \\ 1-1 Yanagido Gifu-shi, Gifu 501-1193, Japan \\ ${ }^{2}$ Department of Materials Science and Technology, Gifu University, \\ 1-1 Yanagido Gifu-shi, Gifu 501-1193, Japan \\ ${ }^{3}$ Division of Instrument Analysis, Life Science Research Center, Gifu University, \\ 1-1 Yanagido Gifu-shi, Gifu 501-1193, Japan
}

Keywords: Steam Reforming, Desulfurized Kerosene, Pd Membrane Deactivation

Hydrogen production using a Pd membrane reformer from desulfurized kerosene is attractive in view of the portable and domestic use of fuel cells. In the present study, membrane reforming of desulfurized kerosene with a pre-reformer was carried out and compared to that of dodecane, which is the main compound in kerosene. The reactivity of desulfurized kerosene was much lower than that of dodecane, resulting in the low performance of the membrane reformer for desulfurized kerosene. In the pre-reforming and membrane reforming of model kerosene (a mixture of dodecane and $m$-xylene), the performance of the pre-reformer and membrane reformer exhibited a similar trend to those for desulfurized kerosene. This low performance of the membrane reformer may be ascribed to the lowering of Pd membrane performance. From the evaluation of Pd membrane performance in the presence of co-products in the pre-reforming of desulfurized kerosene and model kerosene, polycyclic aromatics such as naphthalenes, anthracene and pyrene reduced the $\mathrm{H}_{2}$ permeability of $\mathrm{Pd}$ membranes.

\section{Introduction}

With the increasing attention to global warming, clean and renewable energy is now considered to be essential to solve this world-wide problem. Hydrogen is one of the candidates as clean energy and several hydrogen carrier investigations have been ongoing such as into ammonia (Klerke et al., 2008) and methyl cyclohexane (Okada, 2012). However, since the realization of a hydrogen society through those hydrogen carrier systems will take a long time, fossil fuels assume an important role as a bridging hydrogen carrier for the time being. Steam reforming is a well-established hydrogen production process and has been often used for hydrogen production from a wide variety of hydrocarbons such as natural gas (Kikuchi et al., 1974; Yamaguchi and Iglesia, 2010), liquefied petroleum gas (LPG) (Suzuki et al., 2001; Ahmed et al., 2002), naphtha (Melo and Morlanés, 2005) in petroleum and chemical industries. However, the process efficiency for hydrogen production must be improved before hydrogen can be used as an energy source for fuel cells. Membrane reformers are expected to be one promising technology to produce hydrogen with high energy efficiency because extremely purified hydrogen with higher hydrogen yield than the thermodynamic equilibrium can be obtained

Received on March 25, 2016; accepted on June 10, 2016 DOI: $10.1252 /$ jcej.16we091

Correspondence concerning this article should be addressed to $\mathrm{S}$. Uemiya (E-mail address: uemiya@gifu-u.ac.jp). in one-step owing to simultaneous hydrogen separation through palladium membranes in the reformer (Uemiya et al., 1990). Therefore, hydrogen production using a Pd membrane reformer has been extensively investigated from several fuels such as methane (Uemiya et al., 1990; Tong et al., 2005), LPG (Rakib et al., 2010), liquid hydrocarbons (Itoh et al., 2003), and alcohols (Gallucci and Basile, 2008).

Considering portable and domestic use with an increasing attention to fuel cells, kerosene is an attractive hydrogen source because of its easy availability and safety. Owing to the low reactivity of desulfurized kerosene, catalyst development has been the main research for steam reforming of desulfurized kerosene so far (Muramoto et al., 2009; Miyamoto et al., 2015) and less investigation concerning membrane reforming of desulfurized kerosene has been reported. Previously, we investigated the membrane reforming of dodecane to evaluate the membrane reforming of desulfurized kerosene and found that the pre-reforming was essential to achieve sufficient performance of Pd membrane reformers because of its low reactivity (Miyamoto et al., 2011). In this study, we evaluated the performance of preand membrane reforming of desulfurized kerosene. From the comparison to dodecane, we report the negative effect of co-products in the membrane reforming of desulfurized kerosene on the Pd membrane performance, which is one of the significant lowering factor for the performance of membrane reformer. 


\section{Experimental}

\subsection{Preparation of Pd membrane}

A porous $\alpha$-alumina tube (OD: $10 \mathrm{~mm}$, ID: $7 \mathrm{~mm}$, length: $30 \mathrm{~cm}$, pore size $0.1 \mu \mathrm{m}$, NGK INSULATORS, Ltd.) was used as a support. A Pd thin layer was deposited by electroless plating on the support. The details of the electroless plating are described in our previous study (Uemiya et al., 1988). The porous $\alpha$-aluminum tube was washed ultrasonically by ethanol. After drying, Pd nuclei were supported on the outer surface of the porous $\alpha$-alumina tube by sensitization and activation treatments with stannous chloride and palladium chloride solutions, respectively. These treatments were repeated three times. Then, the palladium nuclei was sufficiently reduced in a hydrazine solution. Palladium was autocatalytically deposited on the outer surface of the porous $\alpha$-alumina tube in an electroless plating bath containing a tetraammine complex of palladium, ethylenediamine tetraacetic acid, ammonium hydroxide and hydrazine. Except for the effective membrane area $(5 \mathrm{~cm}$ length at the center of the support), a thick Ag layer was deposited by electroless plating to inhibit hydrogen permeation.

\subsection{Reaction tests}

Pre-reforming was carried out by using a fixed bed reactor over $\mathrm{Ru} / \alpha-\mathrm{Al}_{2} \mathrm{O}_{3}(2.0 \mathrm{wt} \% \mathrm{Ru}$, N.E. CHEMCAT Corporation) at $873 \mathrm{~K}$. Dodecane, desulfurized kerosene and model kerosene (20 wt $\% m$-xylene/dodecane mixture) were used as fuel. Fuel and water were vaporized and mixed at the steam to carbon ratio, $S / C$, of 3 and supplied to the pre-reformer. The outlet gas passed through an ice trap to recover heavy residual oil including the feed fuel. For the performance evaluation of Pd membrane reformer, the outlet gas from the pre-reformer was successively introduced to the Pd membrane reformer. The membrane reforming was performed at $773 \mathrm{~K}$ and atmospheric pressure. The heavy residual oil at the retentate side was recovered from the outlet gas of membrane reformer by the ice trap. The outlet gas composition through the ice trap was analyzed by gas chromatography and the flow rate was measured by a soap film meter. The composition of heavy residual oil was confirmed by gas chromatography mass spectroscopy analysis (GC-MS). The flow rate and gas composition at the permeate side were analyzed as well.

\subsection{Permeation tests}

$\mathrm{H}_{2}$ permeation tests using $\mathrm{Pd}$ membranes were performed at $773 \mathrm{~K}$ and atmospheric pressure. The permeated $\mathrm{H}_{2}$ was swept under an Ar flow. The flow rates in both the retentate and permeate sides were measured by soap film meters, and the gas composition in the permeate side was analyzed by gas chromatography. To evaluate the effect of hydrocarbons/ aromatics on the Pd membrane performance, hydrocarbons or aromatics $\left(\mathrm{C}_{2}-\mathrm{C}_{3}\right.$ mixture, dodecane, desulfurized kerosene, $m$-xylene, naphthalene, anthracene and pyrene) were supplied with $\mathrm{H}_{2}$. It was noted that polycyclic aromatics were supplied by dissolving in dodecane. During the per-
Table 1 Partial pressure of additives in $\mathrm{H}_{2}$ permeation tests

\begin{tabular}{lccc}
\hline & \multicolumn{3}{c}{ Partial pressure [kPa] } \\
\cline { 2 - 4 } & $\begin{array}{c}\text { Hydrocarbons/ } \\
\text { Aromatics }\end{array}$ & $\mathrm{H}_{2}$ & $\begin{array}{c}\text { Dodecane } \\
\text { (solvent) }\end{array}$ \\
\hline $\mathrm{C}_{2}-\mathrm{C}_{3}$ & 6.3 & 95.0 & - \\
Dodecane & 2.2 & 99.1 & - \\
Desulfurized kerosene & 2.2 & 99.1 & - \\
m-Xylene & 3.4 & 97.9 & - \\
Naphthalene & $4.9 \times 10^{-1}$ & 91.4 & 9.3 \\
Anthrasene & $3.5 \times 10^{-3}$ & 99.6 & 1.7 \\
Pyrene & $3.5 \times 10^{-3}$ & 99.6 & 1.7 \\
\hline
\end{tabular}

meation tests, the mixture of $\mathrm{H}_{2}$ and Ar (balance) was supplied in the first $20 \mathrm{~min}$, and vaporized hydrocarbons and aromatics co-existed with the $\mathrm{H}_{2}$ flow for the next $20 \mathrm{~min}$. This procedure was repeated and the performance deterioration of $\mathrm{Pd}$ membranes was determined by the relative $\mathrm{H}_{2}$ permeability, which is the ratio of $\mathrm{H}_{2}$ permeability in the co-existence of additives to that under $\mathrm{H}_{2} / \mathrm{Ar}$ mixture feed without additives. The partial pressures of the feed components is summarized in Table $\mathbf{1 .}$

\section{Results and Discussion}

\subsection{Pre-reforming of dodecane, desulfurized kerosene and model kerosene}

Figure 1 shows the conversion of fuels to $C_{1}$ products as a function of $W / F$. The conversion of dodecane was achieved

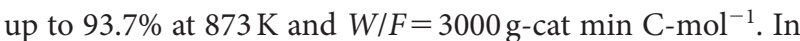
contrast, the conversion of desulfurized kerosene was only $83.1 \%$ at the same reaction condition, and was achieved at a similar conversion to those in pre-reforming of dodecane at more than $6000 \mathrm{~g}$-cat $\mathrm{min} \mathrm{C}-\mathrm{mol}^{-1}(94.3 \%$ and $96.8 \%$ at the $W / F=6000$ and 9000 g-cat $\min \mathrm{C}-\mathrm{mol}^{-1}$, respectively). These results clearly exhibited that the reactivity of desulfurized kerosene was lower than that for dodecane, although the $\mathrm{H}_{2}$ yield in pre-reforming of desulfurized kerosene was slightly lower or comparable to those of dodecane. The low reactivity of desulfurized kerosene may be attributed to the variety of compounds containing aromatics which was nearly $20 \mathrm{vol} \%$. Figure 2 shows the selectivity of $\mathrm{C}_{1}$ products $\left(\mathrm{C}_{1}\right.$ selectivity) in reference to Figure 1. For dodecane, the chemical composition of $\mathrm{C}_{1}$ products corresponded to the thermodynamic equilibrium even at slightly lower conversion to $\mathrm{C}_{1}$ products. On the other hand, the $\mathrm{CO}_{2}$ composition was relatively high with low $\mathrm{CH}_{4}$ composition at $W / F=3000 \mathrm{~g}$-cat $\mathrm{min} \mathrm{C}-\mathrm{mol}^{-1}$ for desulfurized kerosene compared to those of dodecane. This implies that the reaction rate in $\mathrm{C}_{1}$ chemistry was possibly lower in prereforming of desulfurized kerosene than that of dodecane owing to a large number of components in desulfurized kerosene. With an increase in conversion to $\mathrm{C}_{1}$ products, the $\mathrm{C}_{1}$ selectivity approached the thermodynamic equilibrium in pre-reforming of desulfurized kerosene and no significant difference in conversion to $C_{1}$ products and $C_{1}$ selectivity was observed at $3000 \mathrm{~g}$-cat $\mathrm{min} \mathrm{C}-\mathrm{mol}^{-1}$ for dodecane and 


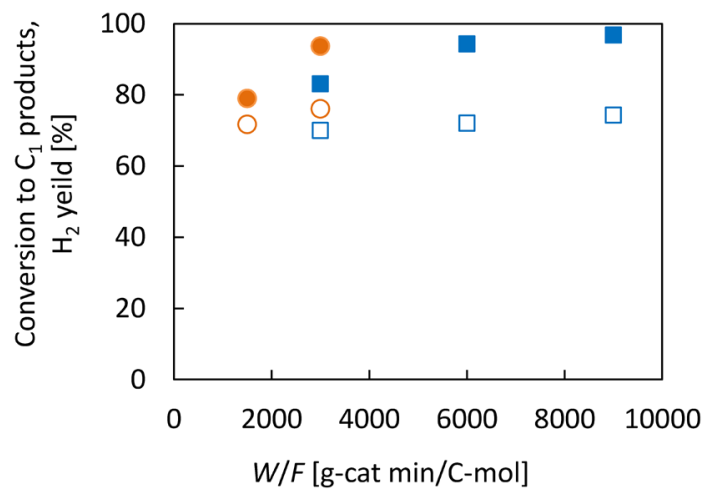

Fig. 1 Conversion to $C_{1}$ products after $180 \mathrm{~min}$ reaction in the prereforming of dodecane and desulfurized kerosene at $873 \mathrm{~K}$ $S / C=3$; circles: dodecane, squares: desulfurized kerosene; filled symbol: conversion to $\mathrm{C}_{1}$ products, open symbol: $\mathrm{H}_{2}$ yield

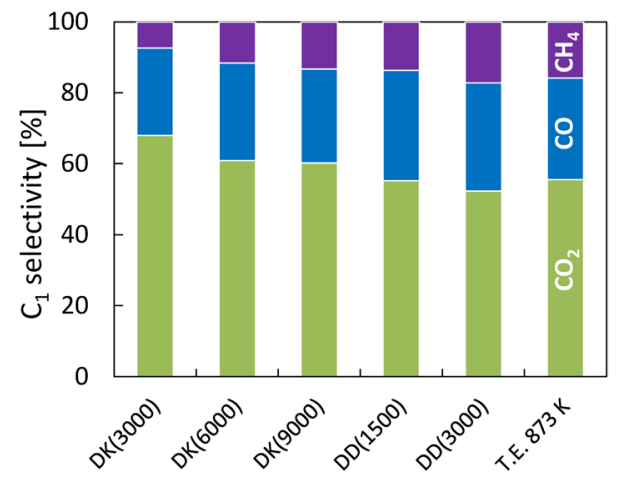

Fig. $2 \mathrm{C}_{1}$ selectivity in pre-reforming of dodecane and desulfurized kerosene at $873 \mathrm{~K}$; DK: desulfurized kerosene, DD: dodecane, T.E.: thermodynamic equilibrium, figures in parentheses were $W / F$ [g-cat $\mathrm{min} / \mathrm{C}-\mathrm{mol}]$

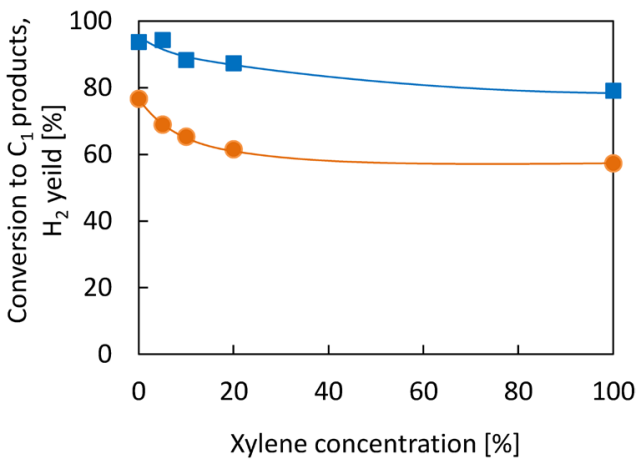

Fig. 3 Conversion to $\mathrm{C}_{1}$ products and $\mathrm{H}_{2}$ yield in pre-reforming of model kerosene as a function of xylene concentration at $873 \mathrm{~K} . \mathrm{S} / \mathrm{C}=3, W / F=3000 \mathrm{~g}$-cat $\mathrm{min} / \mathrm{C}$-mol; circles: $\mathrm{H}_{2}$ yield, squares: conversion to $\mathrm{C}_{1}$ products

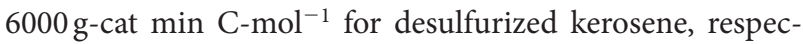
tively, assuming that the membrane reformer shows the comparable performance at those pre-reforming conditions in both reactants.

Figures 3 and 4 show the conversion to $C_{1}$ products and

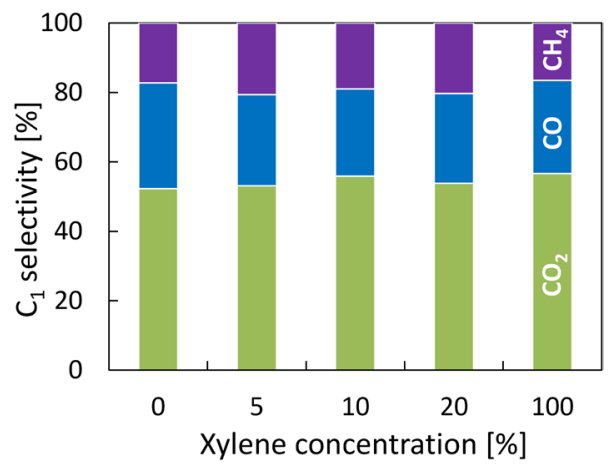

Fig. $4 \mathrm{C}_{1}$ selectivity in pre-reforming of model kerosene as a function of xylene concentration at $873 \mathrm{~K} . S / C=3, W / F=3000$ g-cat $\mathrm{min} / \mathrm{C}-\mathrm{mol}$

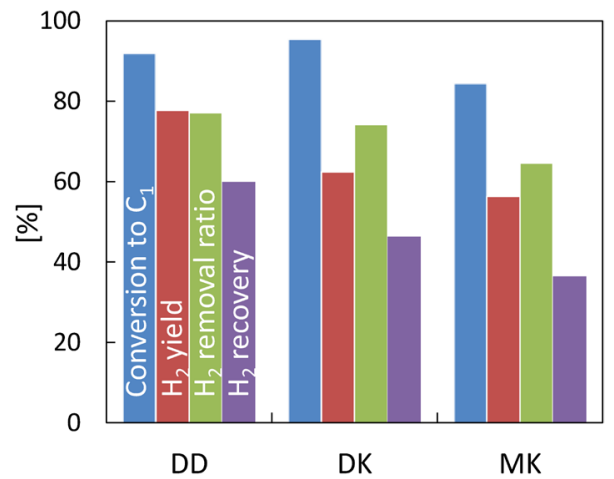

Fig. 5 Performance of membrane reformer in steam reforming of dodecane (DD), desulfurized kerosene (DK) and model kerosene (MK, 20wt\% $m$-xylene/dodecane) at $773 \mathrm{~K} . S / C=3$. $W / F=3000 \mathrm{~g}$-cat $\mathrm{min} / \mathrm{C}$-mol; pre-reforming condition: $873 \mathrm{~K}$, $W / F=3000 \mathrm{~g}$-cat $\mathrm{min} / \mathrm{C}$-mol for dodecane and model kerosene, $6000 \mathrm{~g}$-cat min/C-mol for desulfurized kerosene

$\mathrm{C}_{1}$ selectivity as a function of xylene concentration in prereforming of model kerosene. As expected, the conversion to $\mathrm{C}_{1}$ products and $\mathrm{H}_{2}$ yield were gradually decreased with an increase in xylene concentration, which indicates the aromatics have a negative effect to catalytic activity. However, the $\mathrm{C}_{1}$ selectivity was stable at all xylene concentrations and very similar to those of dodecane. Considering the difference in $\mathrm{C}_{1}$ selectivity in pre-reforming of desulfurized kerosene from those of dodecane and model kerosene, xylene may decrease the degradation rate of reactants to $C_{1}$ products, but that did not influence the reaction kinetics of $\mathrm{C}_{1}$ products.

\subsection{Performance of membrane reformer}

Figure 5 summarizes the performance of membrane reformer in steam reforming of dodecane, desulfurized kerosene and model kerosene. $\mathrm{H}_{2}$ removal ratio and $\mathrm{H}_{2}$ recovery are defined as follows.

$$
\begin{aligned}
& \mathrm{H}_{2} \text { removal ratio }=\frac{\mathrm{H}_{2} \text { permeation rate }}{\mathrm{H}_{2} \text { production rate }} \times 100 \\
& \mathrm{H}_{2} \text { recovery }=\frac{\mathrm{H}_{2} \text { permeation rate }}{\text { Stoichiometric } \mathrm{H}_{2} \text { production rate }} \times 100
\end{aligned}
$$




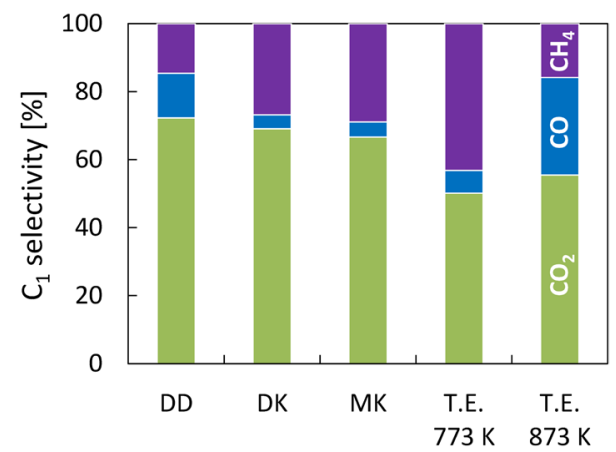

Fig. $6 C_{1}$ selectivity in membrane reforming of dodecane (DD), desulfurized kerosene (DK) and model kerosene (MK, $20 \mathrm{wt} \%$ $m$-xylene/dodecane), T.E.: thermodynamic equilibrium at $773 \mathrm{~K} . \mathrm{S} / \mathrm{C}=3 . \quad W / F=3000 \mathrm{~g}$-cat $\mathrm{min} / \mathrm{C}$-mol; pre-reforming condition: $873 \mathrm{~K}, W / F=3000 \mathrm{~g}$-cat $\mathrm{min} / \mathrm{C}$-mol for dodecane and model kerosene, $6000 \mathrm{~g}$-cat $\mathrm{min} / \mathrm{C}$-mol for desulfurized kerosene

The conversion to $\mathrm{C}_{1}$ products in the membrane reforming of desulfurized kerosene was slightly high compared to that for dodecane because of higher W/F in the pre-reforming, but the $\mathrm{H}_{2}$ yield was significantly low and found to be similar to those for model kerosene where the conversion to $\mathrm{C}_{1}$ product was the lowest in those fuels. It should be noted that the $\mathrm{H}_{2}$ yield was clearly related to both the $\mathrm{H}_{2}$ removal ratio and $\mathrm{H}_{2}$ recovery. These two factors exhibit the performance of Pd membranes in the membrane reformers, and the low $\mathrm{H}_{2}$ removal ratio and $\mathrm{H}_{2}$ recovery suggest that these fuels and/or co-products after pre-reforming reduced the $\mathrm{Pd}$ membrane performance. From the $\mathrm{C}_{1}$ selectivity as shown in Figure 6, in the membrane reforming of dodecane, the $\mathrm{CH}_{4}$ selectivity was unchanged from that in the pre-reforming and the increased $\mathrm{CO}_{2}$ selectivity indicates that selective $\mathrm{H}_{2}$ removal through the Pd membrane effectively shifted the thermodynamic equilibrium, resulting in high $\mathrm{H}_{2}$ yield. Indeed, the $\mathrm{H}_{2}$ yield was the same as the theoretical one at the thermodynamic equilibrium estimated by $\mathrm{H}_{2}$ recovery as shown in Figure 7. Contrary to dodecane, in the membrane reforming of desulfurized kerosene and model kerosene, a significant increase of $\mathrm{CH}_{4}$ selectivity was observed, although $\mathrm{CO}_{2}$ selectivity was slightly increased as well. Comparing the equilibrium $\mathrm{C}_{1}$ selectivity between 773 and $873 \mathrm{~K}$, the $\mathrm{C}_{1}$ selectivity is likely to approach the thermodynamic equilibrium at $773 \mathrm{~K}$. In other words, high $\mathrm{CH}_{4}$ selectivity is due to preferential $\mathrm{CO}$ hydrogenation rather than $\mathrm{CO}$ shift reaction, indicating that the $\mathrm{Pd}$ membrane performance was lower than that in the membrane reforming of dodecane. As a result thereof, the $\mathrm{H}_{2}$ yield in the membrane reforming of desulfurized kerosene and model kerosene decreased from those in the pre-reforming (Figure 7).

Considering the results in membrane reforming, the reactants and/or co-products possibly have a negative effect on the Pd membrane performance. Thus, the co-products were analyzed in the pre-reforming of desulfurized kerosene and model kerosene. Figure 8 shows the $\mathrm{C}_{2}$ and $\mathrm{C}_{3}$ composition in the outlet gas of pre-reforming as a function of xylene

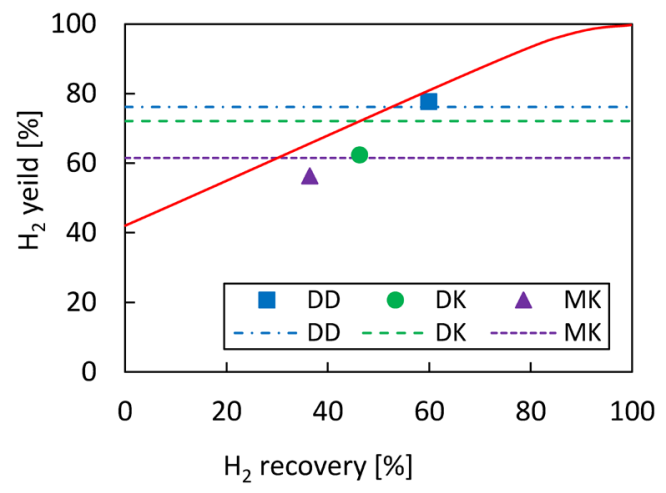

Fig. $7 \mathrm{H}_{2}$ yield in the membrane reforming dodecane (DD), desulfurized kerosene (DK) and model kerosene (MK, $20 \mathrm{wt} \%$ $m$-xylene/dodecane) at $773 \mathrm{~K}$; solid line: thermodynamic equilibrium estimated by $\mathrm{H}_{2}$ recovery, dashed line: $\mathrm{H}_{2}$ yield in prereforming

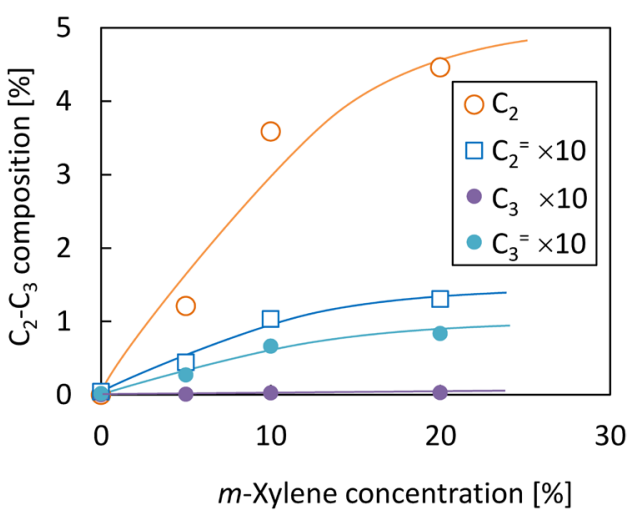

Fig. $8 \quad \mathrm{C}_{2}-\mathrm{C}_{3}$ product composition in pre-reforming of model kerosene as a function of xylene concentration

concentration in model kerosene. In the pre-reforming of dodecane ( $0 \%$ xylene concentration in Figure 8), the concentration of $\mathrm{C}_{2}$ and $\mathrm{C}_{3}$ gases were under the detection limits, suggesting degraded dodecane was immediately converted to $\mathrm{C}_{1}$ products. In contrast, the composition of $\mathrm{C}_{2}-\mathrm{C}_{3}$ products increased with an increase in xylene concentration in the feed. It is well-known that olefins (ethylene and propylene) are readily reacted and produce carbonaceous species (Cai et al., 2002). Additionally, considering the concentration of aromatics decreased the conversion to $\mathrm{C}_{1}$ products (Figure 3), the changes in aromatics contents have an impact on the performance of membrane reformer because aromatics also pose coking problems (Trimm, 1997). The product distributions of heavy residual oil, which was recovered from an ice trap in the pre-reforming of desulfurized kerosene, exhibited the residual oil included much more heavy compounds than desulfurized kerosene, and polycyclic aromatics such as alkylnaphthalenes, anthracene and pyrene were notably increased as in the Figure 9, although the estimated concentration of those polycyclic aromatics in the outlet gas was very low as summarized in Table 2. For prereforming of dodecane, however, no polycyclic aromatics 


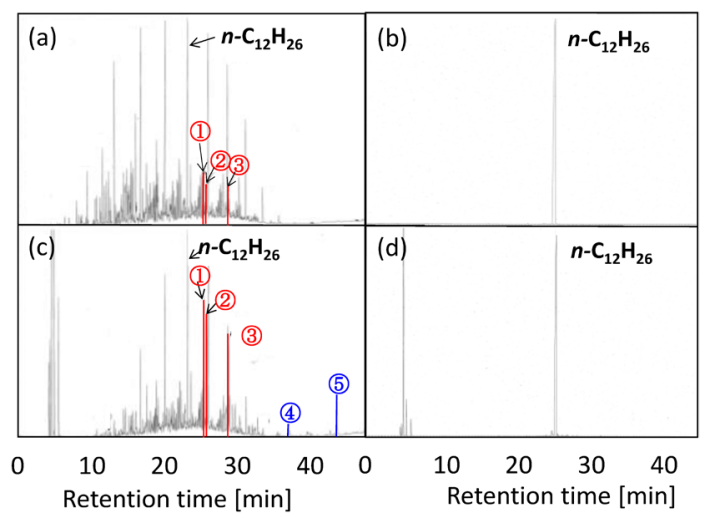

Fig. 9 Gas chromatograph of (a) desulfurized kerosene, (b) dodecane, and residual oil in pre-reforming of (c) desulfurized kerosene and (d) dodecane; the numbers in the figure are (1) 2-methylnaphthalene, (2) 1-methylnaphthalene, (3) 1,5-dimethylnaphthalene, (4) anthracene and (5) pyrene

Table 2 Concentration of polycyclic aromatics in products in prereforming of desulfurized kerosene

\begin{tabular}{lc}
\hline & Concentration [\%] \\
\hline Naphthalene & 0.18 \\
Anthrasene & $<1.0 \times 10^{-3}$ \\
Pyrene & $<1.0 \times 10^{-3}$ \\
\hline
\end{tabular}

were observed in the residual oil.

\subsection{Influence of additives on Pd membrane performance}

From the results as mentioned above, the decrease in $\mathrm{Pd}$ membrane performance may be ascribed to reactants and/or co-products, particularly olefins and aromatics. Then, the Pd membrane performance was evaluated in the presence of those compounds. Figure 10 shows the relative $\mathrm{H}_{2}$ permeability which is defined as the ratio of $\mathrm{H}_{2}$ permeability with additives and without additives. The concentration of additives shown in Table 1 was adjusted over those in the outlet gas of pre-reforming as shown in Table 2. The relative $\mathrm{H}_{2}$ permeability for dodecane, $m$-xylene, desulfurized kerosene and $\mathrm{C}_{2}-\mathrm{C}_{3}$ mixture was found to be over 1 , indicating those compounds did not reduce the Pd membrane performance. It should be noted that the relative permeability for $m$-xylene and desulfurized kerosene reached 1.05 at the initial stage. This is attributed to the gradual activation of Pd membranes during the permeation tests. On the other hand, it is interesting to note that the relative $\mathrm{H}_{2}$ permeability for naphthalene, anthracene and pyrene was less than 1 and the results clearly exhibited that these polycyclic aromatics decreased the Pd membrane performance. However, as shown in Figure 11, the decreased $\mathrm{H}_{2}$ permeation flux by polycyclic aromatics could be recovered to the initial value by the feed of $\mathrm{H}_{2}$ and Ar. Therefore, this lowering of Pd membrane performance might be caused by physical adsorption of those compounds on the Pd membrane surface.
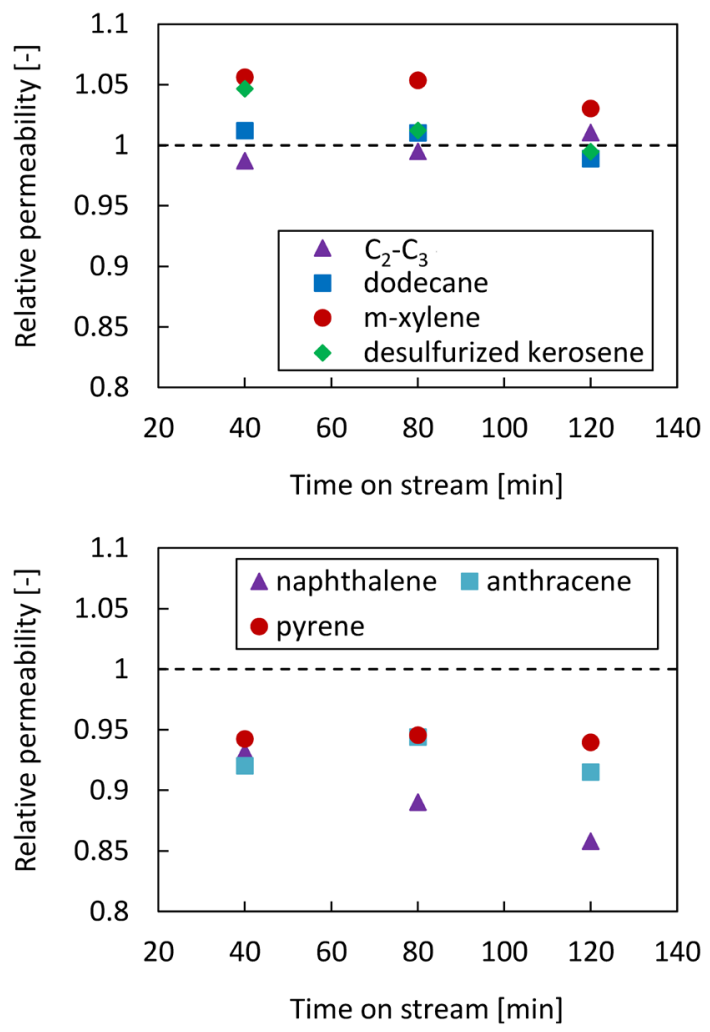

Fig. 10 Effect of hydrocarbons and aromatics on Pd membrane performance at $773 \mathrm{~K}$

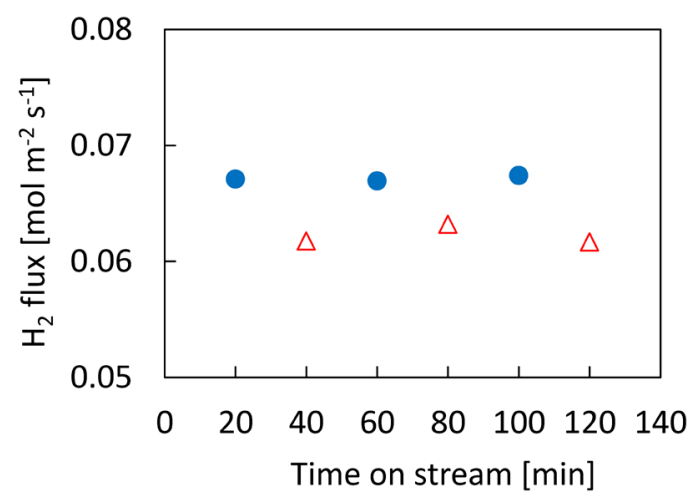

Fig. $11 \mathrm{H}_{2}$ permeation flux on Pd membrane with co-existing of anthracene at $773 \mathrm{~K}$ with anthracene (triangles) and without anthracene (circles)

\section{Conclusions}

Pre-reforming and membrane reforming of desulfurized kerosene and model kerosene were evaluated and compared to those of dodecane. The reactivity of desulfurized kerosene in pre-reforming was significantly lower than that of dodecane. From the pre-reforming of model kerosene, the conversion to $\mathrm{C}_{1}$ products decreased with an increase in xylene concentration. For membrane reforming, the $\mathrm{H}_{2}$ yield for desulfurized kerosene was significantly lower compared to that for dodecane, owing to the lower $\mathrm{H}_{2}$ membrane performance, although the conversions were similar. From the 
evaluation of co-products, $\mathrm{C}_{2}-\mathrm{C}_{3}$ gases and polycyclic aromatics were found to increase after pre-reforming and the effect of these compounds on Pd membrane performance was evaluated. As a result thereof, lowering of the $\mathrm{H}_{2}$ permeability of the Pd membrane was observed in the presence of polycyclic aromatics. This indicates that polycyclic aromatics are poisoning compounds to Pd membranes which caused the lowering of membrane reformer performance. However, this negative effect is expected to be reversible.

\section{Literature Cited}

Ahmed, K., J. Gamman and K. Föger; "Demonstration of LPG-Fueled Solid Oxide Fuel Cell Systems," Solid State Ion., 152-153, 485-492 (2002)

Cai, H., A. Krzywicki and M. C. Oballa; "Coke Formation in Steam Crackers for Ethylene Production," Chem. Eng. Process., 41, 199214 (2002)

Gallucci, F. and A. Basile; "Pd-Ag Membrane Reactor for Steam Reforming Reactions: A Comparison between Different Fuels," Int. J. Hydrogen Energy, 33, 1671-1687 (2008)

Itoh, N., W. C. Xu, S. Hara, K. Kakehida, Y. Kaneko and A. Igarashi; "Effects of Hydrogen Removal on the Catalytic Reforming of $n$ Hexane in a Palladium Membrane Reactor," Ind. Eng. Chem. Res., 42, 6576-6581 (2003)

Kikuchi, E., S. Tanaka, Y. Yamazaki and Y. Morita; "Steam Reforming of Hydrocarbons on Noble Metal Catalysts (Part 1)," Bull. Jpn. Pet. Inst., 16, 95-98 (1974)

Klerke, A., C. H. Christensen, J. K. Nørskovb and T. Vegge; "Ammonia for Hydrogen Storage: Challenges and Opportunities," J. Chem. Mater., 18, 2304-2310 (2008)

Melo, F. and N. Morlanés; "Naphtha Steam Reforming for Hydrogen Production," Catal. Today, 107-108, 458-466 (2005)

Miyamoto, M., C. Hayakawa, K. Kamata, M. Arakawa and S. Uemiya;
"Influence of the Pre-reformer in Steam Reforming of Dodecane Using a Pd Alloy Membrane Reactor," Int. J. Hydrogen Energy, 36, 7771-7775 (2011)

Miyamoto, M., M. Arakawa, Y. Oumi and S. Uemiya; "Influence of Metal Cation Doping on $\mathrm{Ru} / \mathrm{CeO}_{2} / \mathrm{Al}_{2} \mathrm{O}_{3}$ Catalyst for Steam Reforming of Desulfurized Kerosene," Int. J. Hydrogen Energy, 40, 2657-2662 (2015)

Muramoto, T., K. Nariai, H. Ohara and H. Kamata; "Durability of Ru/ $\mathrm{CeO}_{2} / \gamma-\mathrm{Al}_{2} \mathrm{O}_{3}$ Catalyst for Steam Reforming of Dodecane," J. Jpn. Petrol. Inst., 52, 108-113 (2009)

Okada, Y.; "Large Scale $\mathrm{H}_{2}$ Storage and Transportation System by Organic Chemical Hydride Method (in Japanese)," J. Jpn. Inst. Energy, 91, 473-478 (2012)

Rakib, M. A., J. R. Grace, C. J. Lim, S. S. E. H. Elnashaie and B. Ghiasi; "Steam Reforming of Propane in a Fluidized Bed Membrane Reactor for Hydrogen Production," Int. J. Hydrogen Energy, 35, 6276-6290 (2010)

Suzuki, T., H. Iwanami, O. Iwamoto and T. Kitahara; "Pre-reforming of Liquefied Petroleum Gas on Supported Ruthenium Catalyst," Int. J. Hydrogen Energy, 26, 935-940 (2001)

Tong, J., Y. Matsumura, H. Suda and K. Haraya; "Experimental Study of Steam Reforming of Methane in a Thin $(6 \mu \mathrm{M})$ Pd-Based Membrane Reactor," Ind. Eng. Chem. Res., 44, 1454-1465 (2005)

Trimm, D. L.; "Coke Formation and Minimisation during Steam Reforming Reactions," Catal. Today, 37, 233-238 (1997)

Uemiya, S., N. Sato, H. Ando, T. Matsuda and E. Kikuchi; "Steam Reforming of Methane in a Hydrogen-Permeable Membrane Reactor," Appl. Catal., 67, 223-230 (1990)

Uemiya, S., Y. Kude, K. Sugino, N. Sato, T. Matsuda and E. Kikuchi; "A Palladium/Porous-Glass Composite Membrane for Hydrogen Separation," Chem. Lett., 17, 1687-1690 (1988)

Yamaguchi, A. and E. Iglesia; "Catalytic Activation and Reforming of Methane on Supported Palladium Clusters," J. Catal., 274, 52-63 (2010) 